\title{
MODEL PEMBELAJARAN RADEC UNTUK MENINGKATKAN HIGHER ORDER THINGKING SKILL DALAM PEMBELAJARAN IPS DI SEKOLAH DASAR
}

\author{
Triska Rindiana ${ }^{1}$, Muh. Husen Arifin ${ }^{2}$, Yona Wahyuningsih ${ }^{3}$ \\ $1,2,3$ Universitas Pendidikan Indonesia \\ Email: triskarindiana@upi.edu \\ Email: muhusenarifin@upi.edu \\ Email: yonawahyuningsih@upi.edu
}

\begin{abstract}
Abstrak
Pesatnya perkembangan ilmu pengetahuan dan teknologi di abad 21 sangatlah penting keterampilan seperti HOTS. Di Indonesia, dalam penerapannya di lapangan HOTS belum sepenuhnya dicapai, dikarenakan pelaksanaan model pembelajaran yang sulit diingat oleh guru dalam sintaksnya. Penelitian ini bertujuan untuk mengetahui model pembelajaran RADEC untuk meningkatkan HOTS pada pembelajaran IPS di sekolah dasar. Metode yang digunakan dalam penelitian ini adalah systematic review yaitu penelaahan terhadap penelitian-penelitian sebelumnya. Hasil dari penelitian ini adalah HOTS dalam pembelajaran IPS menjadi suatu hal yang snagat penting yang harus dikembangkan oleh guru, dikarenakan pada Abad 21 HOTS menjadi salah satu keterampilan yang sangat penting dimiliki siswa untuk menjawab tantangan abad 21 . Salah satu model pembelajaran yang dapat diaplikasikan untuk meningkatkan HOTS adalah RADEC yang dimulai dari ReadAnswer-Discuss-Explain-Create. Tahapan tersebut jelas dapatmebangun HOTS karena dalam model pembelajaran RADEC siswa dituntut untuk menganalisis dan mencipta.
\end{abstract}

Kata Kunci: Abad 21, Hots, Radec

\begin{abstract}
In the development of science and technology in the 21st century, skills such as HOTS are very important. In Indonesia, its implementation in the HOTS field has not been fully achieved, due to the implementation of a learning model that is difficult for teachers to remember in its syntax. This study aims to determine the RADEC learning model to improve HOTS in social studies learning in elementary schools. The method used in this study is a systematic review, namely a review of previous studies. The result of this study is that HOTS in social studies learning becomes a very important thing that must be developed by teachers, because in the 21st Century HOTS is one of the most important skills students have to answer the challenges of the 21st century. One of the learning models that can be applied to improve HOTS is RADEC which starts from Read-Answer-Discuss-Explain-Create. These stages can clearly build HOTS because in the RADEC learning model students are required to analyze and create.
\end{abstract}

Keywords: 21st Century, Hots, Radec

\section{PENDAHULUAN}

Pesatnya perkembangan ilmu pengetahuan dan teknologi di Abad 21 tentunya memberikan perubahan dan dampak yang berimplikasi dalam berbagai bidang kehidupan di setiap negara termasuk Indonesia yang dituntut untuk mengikuti pengaruh global. (Binkley, M., Erstad, O., Herman, J., Raizen, S., Ripley, M., Miller-Ricci, M., \& Rumble) menyebutkan bahwa untuk mampu mengahdapi tantangan abad 21 ini diperlukan sepuluh keterampian yang harus dimiliki seorang 
siswa. Keterampilan tersebut seperti keterampilan berpikir

keterampilan

keterampilan berpikir metakognisi, komunikasi, kolaborasi, literais informasi, literasi komputer, berkewarganegaraan, bekerja dan berkarir, serta keterampilan responsibilitas individual dan sosial.

Selain itu, untuk memenuhi tuntutan abad 21 (Trilling and Fadel) menggagas konsep pelangi keterampilan dan pengetahuan. Keterampilan tersebut adalah keterampilan belajar dan berinovasi yang meliputi keterampilan berpikir kreatif dan kemampuan problem solving, kemampuan komunikasi dan kolaborasi, serta kemampuan untuk berkreativitas dan berinovasi. Keterampilan-keterampilan tersebut jika dicermati sangatlah erat kaitannya dengan Higher Order Thinking Skill atau kita kenal dengan istilah HOTS.

HOTS merupakan kemampuan penting yang mampu mengakomodasi siswa untuk dapat memenuhi tuntutan zaman, bersaing secara global, yang mana siswa tidak hanya belajar untuk mengingat dan memahami, namun lebih jauh lagi yaitu menganalisis (analyse), mengevaluasi (evaluate), dan menciptakan (create) (Amini and Oktarisma). Karena hal tersebut, HOTS menjadi sebuah kemampan yang cukup rumit yang didalamnya terdapat kemampuan logika dan penalaran, evaluasi, analisis, kreativitas, pemecahan masalah, dan pengambilan keputusan. HOTS ini sangatlah penting jika dikaitkan dengan Abad 21, oleh karena itu dengan membelajarkan HOTS menjadi sebuah tuntutan bagi seorang guru untuk siswanya. Salah satu dampak diterapkannya HOTS adalah memaksimalkan kinerja dan mengurangi kelemahan. Hal ini dapat diaplikasikan kepada siswa untuk berpikir secara HOTS yang akan berdampak pada kemampuan, kecepatan, dan efisiensi dalam pengambilan sebuah keputusan (Heong et al.). Namun , berdasarkan fakta yang ditemukan di lapangan menunjukkan bahwa kemampuan HOTS pada siswa Sekolah Dasar ada pada taraf rendah. Siswa Sekolah Dasar masih belajar dalam taraf mengingat (remember), memahami (understand), dan menerapkan (implement), tetapi belum terbiasa dilatih kemampuan menganalisis, mengevaluasi, dan menciptakan.

Sudah banyak penelitian yang dilakukan mengenai HOTS diantaranya seperti penelitian (Fitri, H., Dasna, I. W., \& Suharjo) yang menyimpulkan bahwa penerapan Model Project Based 
Learning (PBL) dapat meningkatkan HOTS dengan nilai F-hitung sebesar 6,537 yang lebih besar dari nilai F-tabel sebesar 4,067. Selain itu, penelitian (Fauziah, U., \& Fitria) yang menyebutkan Problem Based Learning (PBL) juga meningkatkan HOTS pada siswa seklah dasar. Didukung oleh penelitian (Acar and Tuncdogan) yang menyatakan bahwa pembelajaran berbasis Inkuiri dapat mengembangkan keterampilan HOTS (Higher Order Tinking Skill). Hal tersebut didukung oleh penelitian (Efendi et al.) yang menyebutkan bahwa HOTS dapat ditingkatkan dengan mengaplikasikan model Problem Based Learning dan Discovery Learning. Pernyataan tersebut berdasarkan uji $\mathrm{T}$ yang memperoleh nilai t-hitung seber $-3,6$ lebih kecil dari t-tabel yang menunujukkan bahwa kemampuan berpikir tingkat tinggi (HOTS) dapat ditingkatkan menggunakan Problem Based Learning dan Discovery Learning.

Sayangnya model-model pembelajaran inovatif tersebut tidak dapat terlaksana dengan baik di lapangan. Hasil penelitian sopandi dalam (Pratama, Sopandi, Hidayah, et al.) menyebutkan bahwa hanya $10 \%$ guru pendidikan dasar dan menengah se-Jawa Barat yang bisa menuliskan sintaks dari model pembelajaran inovatif yang sering digunakan. Itu artinya terdapat miskonsepsi guru terhadap model pembelajaran inovatif, sehingga guru hanya merasa melaksanakan pembelajaran inovatif, namun nyatanya tidak. Selain sintaksnya yang sulit dihafal, model pebelajaran inovatif juga memerlukan waktu yang cukup lama dalam satu kali kegiatan pembelajaran. Sehingga guru cenderung lebih banyak menggunakan pembelajaran dengan metode ceramah yang dianggap praktis dan cepat, hal tersebut memberikan dampak pada aktivitas kelas yang didominasi oleh penugasan dan hafalan yang memperlihatkan bahwa rendahnya keterlibatan kemampuan berpikir siswa di dalam pembelajaran.

Berdasarkan pernyataan diatas, maka diperlukan solusi alternatif, salah statunya adalah dengan menghadirkan model pembelajaran yang mudah dihafal sintaknya dan sesuai dengan karakteristik guru dan karaktersitis siswa di Indonesia. Model Pembelajaran tersebut adalah model pembelajaran RADEC (Read-Answer-Discuss-Explain and Create) yang pertama kali diperkenalkan Sopandi dalam (Lestari et al.)). Model pembelajaran RADEC merupakan model pembelajarn yang menggunakan sintaknya sebagai nama model pembelajaran itu sendiri, yaitu 
read atau membaca, answer atau menjawab, discuss atau berdiskusi, explain atau menjelaskan, dan create atau menciptakan. Berbagai penelitian mengenai model pembelajaran RADEC (Read-Answer-Discuss-Explain and Create) sudah dilakukan pada beberapa mata pelajaran selain IPS, diantaranya ada IPA dan Bahasa Indonesia. Berdasarkan hasil penelitian tersebut menunujukkan bahwa model pembelajaran RADEC dapat meningkatkan kemampuan berpikir tingkat tinggi siswa (HOTS).

Seperti penelitian yang dilakukan oleh (Ilham S, Muhammad, Syarifuddin, Kune) yang menyebutkan adanya pengaruh yang signifikan antara model pembelajaran RADEC dengan bantuan aplikasi Zoom terhadap kemampuan berpikir kritis IPA siswa kelas VI SDN Kalukuang 1 Makassar di era pandemi Covid-19 yang ditunjukkan berdasarkan hasil Sig (2 tailed) yaitu 0,000 (Ilham S, Muhammad, Syarifuddin, Kune) Selain itu, penelitian yang dilakukan oleh (Pratama, Sopandi, and Hidayah) yang dapat disimpulkan bahwa model pembelajaran RADEC dapat meningkatkan kemampuan berpikir tingkat tinggi siswa di sekolah dasar yang dilihat berdasarkan skor rata-rata post-test kelas RADEC sebeser 70,08 dibandingkan dari skor rata-rata pretest sebesar 40,44 yang artinya terdapat peningkatan sebesar 29,54 (Pratama, Sopandi, and Hidayah). Hal ini juga didukung oleh penelitian (Fuziani et al.) berdasarkan penilitian (Pratama, Sopandi, and Hidayah) yang berjudul "Pengaruh model pembelajaran RADEC terhadap keterampilan berpikir tingkat tinggi siswa sekolah dasar". Didapatkan hasil bahwa pada kelas eksperimen dan kelas kontrol terdapat perubahan yang signifikan pada hasil test yang dilakukan sebelum dan sesudah penerapan model pembelajaran RADEC, sehingga model pembelajaran RADEC ini dianggap mampu menjadi solusi lain untuk meningkatkan HOTS.

Dengan banyaknya penelitian mengenai model pembelajaran RADEC ini sangatlah penting untuk merincikan hasil penelitian yang ada kemudian dilakukan sintesis dengan system review (Siswanto). Adapun tujuan dari penelitian ini adalah untuk mengetahui model pembelajaran RADEC untuk meningkatkan higher order thinking skill pada pembelajaran IPS di sekolah dasar melalui system review

\section{Metode Penelitian}

Metode penelitian yang digunakan dalam artikel ini adalah systematic review yaitu penelaahan terhadap artikel sebelumnya secara 
terstruktur dan terencana. Torgerson dalam (Hariyati) menyebutkan tujuan dari system review adalah enjawab pertanyaan secara spesifik, relevan, terfokus, mensitesis hasil, menurunkan bias dari review, dan mengidentifikasi gap dari riset. Dengan menggunakan metode ini, penulis ini menjawab pertanyaan penelitian yang sudah disebutkan pada bagian pendahuluan dan untuk menjawab pertanyaanpertanyaan tesebut dibutuhkan langkahlangkah yang sistematis. Diantara langkah-langkah dalam systematic review sebagai berikut:

1. Mendefinisikan tujuan dari review dan menetapkan tipe dari evidence (fakta dan bukti) yang akan membantu menjawab tujuan review. Tujuan dari review ini dibuat untuk mengetahui model pembelajaran RADEC sebagai alternatif dalam meningkatkan higher order thinking skill pada pembelajaran IPS di sekolah dasar. Tipe dari evidence yang digunakan adalah bukti yang memaparkan bahwa model pembelajaran RADEC dapat meningkatkan higher order thinking skill pada pembelajaran IPS di sekolah dasar

2. Mennetukan strategi pencarian literatur, mulai dari artikel yang sudah terpublikasi atau belum, batasan tahun terbit, jenis bahasa yang digunakan, terbatas pada artikel jurnal saja atau menggubakan conference proceding, metode akses jurnal online atau offline. Penelitian ini menggunakan artikel-artikel sebelumnya yang sudah dilakukan penelitian kemudian hasil dari penelitian tersebut di review. Artikel yang digunakan adalah artikel yang sudah terpublikasi mulai dari tahun 2015 hingga 2021, berbahasa Inggris dan Indonesia, dan diakses secara online melalui google scholar dengan kata kunci model pembelajaran RADEC untuk meningkatkan higher order thinking skill pada pembelajaran IPS di sekolah dasar

3. Menetapkan jenis metode penelitian yang digunakan pada artikel yang di review. Jenis model penelitian yang dijadikan bahan review tidak hanya terbatas satu metode saja, namun menggunakan metode kuantitatif dan kuaitatif

4. Mengkombinasikan hasil yaitu mengelompokkan hasil review unuk mendapatkan makna yang dimaksud (evidence sintesis)

5. Mengkominasikan hasil penelitian sebelumnya adalah bagian inti dari system review ini. Artikel-artikel 
yang sesuai dengan tujuan dan evidence yang sudah ditetapkan sebelumnya dikelompokkan untuk melihat hasilnya. Kemudia dri berbagai hasil penelitian tersebut akan disintesis (evidence synthesis)

6. Menetapkan hasil, yaitu menyimpulkan konteks atau suatu hasil dari pengelompokkan review. Langkah terakhir menyimpulkan yaitu hasil pengelompokkan review yang sebelumnya telah dilakukan. Hasil penelitian sebelumnya yang sudah disintesis kemudian disimpulkan sebagai jawaban dari pertanyaan penelitian yang sudah diajukan sebelumnya.

\section{Hasil dan Pembahasan}

Berdasarkan hasil pencarian diperoleh 10 artikel yan dianggap sesuai dengan tema penelitian yang akan diangkat kemudian dijadikan satu dan dilakukan screening apakah kajian pada artikel tersebut sama atau tidak. Setelah dilakukan screening diperoleh 5 artikel yang sesuai dengan kajian yang akan dilakukan oleh penulis. Dari 5 artikel hasil screening ini akan diseleksi kembali berdasarkan eligibility yang telah ditentukan sebelumnya dan diperoleh 3 artikel yang akan di review. Dari 3 artikel yang di review menggunakan dua jenis metode penelitian yaitu kualitatif dan eksperimen. Dari 3 artikel ini dilakukan ekstraksi data dengan menganalisa data berdasarkan nama penulis, judul, tujuan, metode penelitian, dan hasil yang merupaka data-data penting dalam artikel. Hasil dari ekstraksi data tersebut dapat dilihat dari Tabel 1.

Tabel 1. Hasil ekstraksi data

\begin{tabular}{|c|c|c|c|}
\hline Penulis & $\begin{array}{c}\text { Tujuan } \\
\text { Penelitian }\end{array}$ & $\begin{array}{c}\text { Metode } \\
\text { Penelitian }\end{array}$ & Hasil Penelitian \\
\hline Handayani (2019) & $\begin{array}{l}\text { Untuk } \\
\text { mendeskripsikan } \\
\text { penerapan } \\
\text { model } \\
\text { pembelajaran } \\
\text { RADEC yang } \\
\text { diyakini dapat } \\
\text { meningkatkan } \\
\text { HOTS siswa dan } \\
\text { untuk } \\
\text { mendeskripsikan } \\
\text { perubahan } \\
\text { HOTS siswa }\end{array}$ & $\begin{array}{l}\text { Deskriptif } \\
\text { dan } \\
\text { eksperimen } \\
\text { mingguan }\end{array}$ & $\begin{array}{l}\text { Dalam pembelajaran RADEC } \\
\text { berdasarkan hasil penelitian } \\
\text { menunjukkan bahwa terjadi } \\
\text { peningkatan HOTS siswa dari } \\
\text { rata-rata } 41 \text { menjadi } 84,6 \\
\text { setelah } \\
\text { dilakukan }\end{array}$ \\
\hline
\end{tabular}




\begin{tabular}{|c|c|c|c|}
\hline & $\begin{array}{l}\text { yang terkait } \\
\text { dengan } \\
\text { penerapan } \\
\text { model } \\
\text { pembeljaaran } \\
\text { RADEC sebagai } \\
\text { alternatif model } \\
\text { pembelajaran } \\
\text { HOTS di } \\
\text { sekolah dasar }\end{array}$ & & \\
\hline Fuziani (2021) & $\begin{array}{l}\text { Untuk } \\
\text { merancang } \\
\text { kegiatan } \\
\text { pembelajaran } \\
\text { keberagaman } \\
\text { budaya } \\
\text { Indonesia } \\
\text { dengan } \\
\text { menggunakan } \\
\text { model } \\
\text { pembelajaran } \\
\text { RADEC di SD } \\
\text { kelas IV }\end{array}$ & $\begin{array}{l}\text { Studi } \\
\text { Literatur }\end{array}$ & $\begin{array}{l}\text { Berdasarkan studi literatur } \\
\text { yang dilakukan, model } \\
\text { pembelajaran RADEC } \\
\text { dapat diaplikasikan dalam } \\
\text { kegiatan pembelajaran } \\
\text { keberagaman budaya } \\
\text { Indonesia di kelas IV } \\
\text { sekolah dasar. Dengan } \\
\text { melakukan penerapan } \\
\text { model pembelajaran } \\
\text { RADEC ini dapat } \\
\text { meningkatkan kemampuan } \\
\text { berpikir tingkat tinggi siswa. }\end{array}$ \\
\hline Pratama & $\begin{array}{l}\text { Untuk } \\
\text { mengetahui } \\
\text { pengaruh model } \\
\text { pembelajaran } \\
\text { RADEC } \\
\text { terhadap } \\
\text { keterampilan } \\
\text { berpikir tingkat } \\
\text { tinggi siswa } \\
\text { sekolah dasar }\end{array}$ & $\begin{array}{l}\text { Kuasi } \\
\text { eksperimen } \\
\text { dengan the } \\
\text { matching } \\
\text { pretest- } \\
\text { protest } \\
\text { design }\end{array}$ & 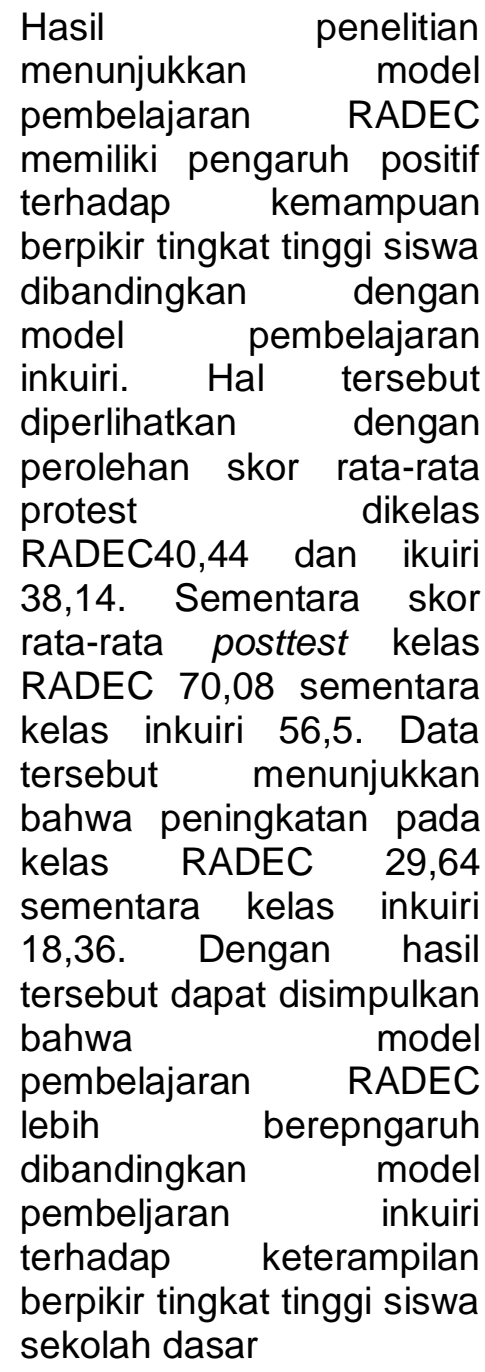 \\
\hline
\end{tabular}


Model pembelajaran Read, ini guru harus bisa membimbing siswa Answer, Discuss, Explain, adn Create dalam proses membaca dengan cara (RADEC) merupakan salah satu model memberikan pertanyaan prayang dikembangkan sesuai dengan pembelajaran yang disusun sesuai karakter bangsa Indonesia (Pratama, dengan indikator pencapaian Sopandi, and Hidayah). Model kompetensi yang harus dicapai oleh pembelajaran RADEC juga merupakan siswa dalam mata pelajaran IPS. salah sau alternatif model pembelajaran Kegiatan membaca ini sangat efektif inovatif yang didasarkan pada sistem dan bermakna.

pendidikan Indonesia dimana siswa Untuk melihat umpan balik siswa ituntut untuk memahami berbagai pada tahap Read, maka tahap konsep ilmu pengetahuan dalam waktu selanjutnya adalah Answer. Pada tahap yang terbatas (Pratama, Sopandi, ini, guru memberikan soal pascaHidayah, et al.). membaca untuk melihat siswa mana Langkah-langkah dari model yang membaca dan siswa mana yang pembelajaran RADEC dapat dilihat tidak membaca. Selanjutnya, kegiatan pada Gambar 1. Model pembelajaran Answer ini bertujuan untuk RADEC diawali dengan tahap Read. menunjukkan bahwa sebelum kegiatan Pada tahap ini, siswa diminta untuk pembelajaran dimulai siswa sudah membaca bahan ajar yang telah guru memahami materi dengan baik. persiapkan sesuai dengan kompetensi Sehingga proses kegiatan dasar dan indikator pencapaian pembelajaran selanjutnya bisa kompetensi. Tahap Read ini dilakukan difokuskan kepada hal-hal atau materi sebelum kegiatan pembelajaran dimulai yang belum dipahami siswa atau dilaksanakan dirumah. Pada tahap

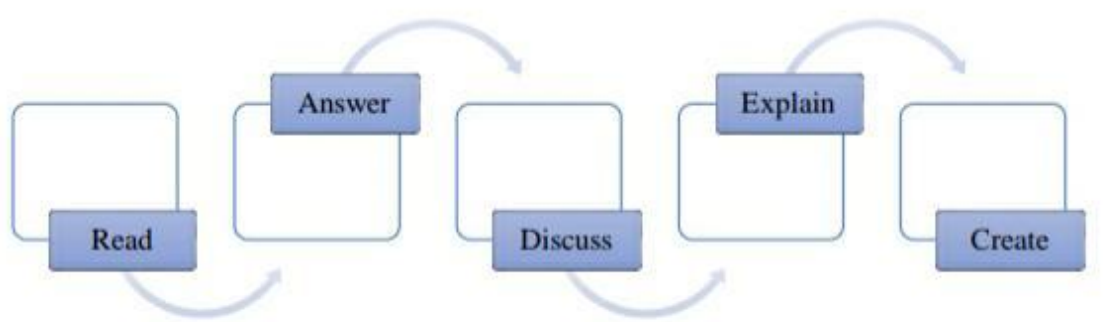

Gambar 1. Langkah-langkah model pembelajaran RADEC 
Selanjutnya, pada tahap Discuss akan terlihat bahwa siswa aktif dan bersemangat, karena siswa sebelumya sudah memiliki bekal materi yang sangat cukup untuk mendiskusikan masalah mengenai mata pelajaran IPS. Meski suasana kelas menjadi ramai dan sempat tidak terkontrol, namun suasana seperti inilah yang dapat membangun Higher Order Thinking Skill atau HOTS yaitu keterampilan berpikir analisis (C4). Hal ini sejalan dengan penelitian Murphy yang menyimpulkan bahwa keterampiln kritis-analisis dapat dibangun melalui diskusi atau percakapan yang menantang. Proses diskusi dalam model pembelajaran RADEC tentu berbeda dengan model pembelajaran inkuiri di kelas kontrol, karena secara konten, siswa yang belajar menggunakan model pembelajaran RADEC sudah lebih matang dan siap. Proses diskusi aktif seperti ini tentu mendorong siswa untuk bertanya dan belajar menggunakan strategi pemecahan masalah, hal tersebutlah yang dapat membangun HOTS (Petrovska and Veselinovska). Lebih khususnya keterampilan evaluasi dalam taksonomi Bloom revisi masuk pada ranah C5 melalui proses pembelajaan yang komunikatif. Proses pembelajaran yang komunikatif memang terbukti baik dalam melatih siswa dalam berpikir, hal ini didukung oleh penelitian pembelajaran bahasa Inggris yang dilakukan oleh jaben menyatakan bahwa HOTS akan terbangun pada tahap manakala siswa saling menilai temannya dengan cara memberi tanggapa terhadap hasil diskusi dari kelompo lain. Dalam memberikan tanggapan tentu diperlukan proses berpikir tingkat tinggi, yakni menilai atau membandingkan.

$$
\text { Kegiatan Explain yang }
$$
menghendaki terjadinya komunikasi seyogyanya merupakan bagian integral dari pembelajaran inovatif seperti yang terdapat dalam sintaks model pembelajaran inkuiri yang sudah terbukti dapat mengembangkan HOTS (Duran and Dökme), namun demikian tahap Explain pada model pembelajaran RADEC lebih interaktif dan komunikatif. Kegiatan presentasi dalam pembelajaran inkuiri cenderung kurang memberikan semangat belajar kepada siswa. Hal tersebut dikarenakan siswa belum sepenuhnya bisa belaja dari proses penyelidikan, berbeda dengan siswa dalam model pembelajaran RADEC yang sebelumnya sudah dibekali materi ajar. Hal ini memberikan bahwa kegiatan presentasi lebih baik pada siswa yang memperoleh pembelajaran RADEC. 
Tahap selanjutnya adalah tahap terakhir dalam model pembelajaran RADEC yaitu Create yang sangat jelas sekali dapat mengembangkan HOTS, karena pada level tertinggi dari HOTS adalah Create atau mencipta. Kegiatan dalam tahap ini adalah mengembangkan ide-ide kreatitf siswa dalam kegiatan pembuatan produk. Pembuatan produk tersebut tidak dibatasi oleh guru, dalam artian guru membebaskan siswa untuk mencari dan mewujudkan ide kreatif mereka kedalam sebuah karya. Hal tersebut sejalan dengan penelitian handayani yang menyimpulkan bahwa model pembelajaran RADEC dapat meningkatkan keterampilan berpikir kreatif siswa. Dengan demikian terdapat relevansi antara model pembelajaran RADEC dengan HOTS, yaitu pada tahap Create kemampuan berpikir kreatif siswa mampu terbangun. Hal tersebut akan terlihat dari ide-ide solutif yang dihasilkan oleh siswa pada kelas esperimen yang sangat kentara dengan level kogniif C-6.

\section{Kesimpulan}

Berdasarkan hasil analisis yang telah dilakukan oleh penulis, dapat ditarik kesimpulan bahwa model pembelajaran RADEC dapat menjadi salah satu alternatif untuk meingkatkan higher order thinking skill dalam pembelajaran IPS di sekolah dasar. HOTS atau higher order thinking skill dalam pembeljaran IPS menjadi suatu hal yang penting yang harus dikembnagkan oleh guru terutama untuk siswa sekolah dasar ditengah kemajuan ilmu pengetahuan dan teknologi di abad 21. HOTS menjadi suatu keterampilan yang penting dan harus dimiliki oleh siswa agar dapat memenuhi tantangan perkembangan zaman sehingga dapat bersaing secara global. Untuk menjawab tantangan tersebut, ada model pembelajaran RADEC yang dimulai dengan tahap Read, Answer, Discus, Explain, dan Create yang dapat membangun higher order thinking skill atau HOTS pada siswa karena sintaksnya disesuaikan dengan karakteristik guru dan siswa di Indonesia. Selain itu RADEC mengaplikasikan keterampilan berpikir HOTS yaitu analyse, evaluate, dan create yang membuat RADEC ini sangat cocok untuk melatih higher order thinking skill siswa.. 


\section{Daftar Pustaka}

Acar, Oguz A., and Aybars Tuncdogan. "Using the Inquiry-Based Learning Approach to Enhance Student Innovativeness: A Conceptual Model." Teaching in Higher Education, vol. 24, no. 7, Routledge, Oct. 2019, pp. 895909, doi:10.1080/13562517.2018.1516636.

Amini, R., and S. Oktarisma. "Pengembangan Modul Pembelajaran IPA Berbasis Picture And Picture Di Sekolah Dasar." Jurnal Basicedu, vol. 5(2), 2021, pp. 835-841., doi:Https://Doi.Org/10.31004/Basicedu.V5i2.769.

Binkley, M., Erstad, O., Herman, J., Raizen, S., Ripley, M., Miller-Ricci, M., \& Rumble, M. "Defining Twenty-First Century Skills. In P. Mcgaw, G. Barry, \& E. Care (Eds.), Assessment And Teaching Of 21st Century Skills." New York: Springer, 2012, doi:Https://Doi.Org/10.1007/978-94-007-2324-5.

Duran, Meltem, and Ilbilge Dökme. "The Effect of the Inquiry-Based Learning Approach on Student's Critical-Thinking Skills." Eurasia Journal of Mathematics, Science and Technology Education, vol. 12, no. 12, 2016, pp. 2887-908, doi:10.12973/eurasia.2016.02311a.

Efendi, Friska, et al. "Perbedaan Model Problem Based Learning Dengan Discovery Learning Terhadap Higher Order Thingking Skills Dan Self Directed Learning Di Sekolah Dasar." Jurnal Basicedu, vol. 5, no. 1, 2020, pp. 301-09, doi:10.31004/basicedu.v5i1.647.

Fauziah, U., \& Fitria, Y. "Peningkatan Kemampuan Berpikir Tingkat Tinggi Siswa Sekolah Dasar Melalui Problem-Based." Primary: Jurnal Pendidikan Guru Sekolah Dasar, vol. 9(2), 2020, pp. 202-12, doi:Https://Doi.Org/10.33578/Jpfkip.V9i2.7881.

Fitri, H., Dasna, I. W., \& Suharjo, S. "Pengaruh Model Project Based Learning (Pjbl) Terhadap Kemampuan Berpikir Tingkat Tinggi Ditinjau Dari Motivasi Berprestasi Siswa Kelas IV Sekolah Dasar." Briliant: Jurnal Riset Dan Konseptual, vol. 3(2), 2018, pp. 201-12, doi:Https://Doi.Org/10.28926/Briliant.V3i2.187.

Fuziani, Indi, et al. Penerapan Model Pembelajaran Radec Dalam Merancang Kegiatan Pembelajaran Keberagaman Budaya Di SD Kelas IV. 2021, pp. 8319-26.

Hariyati, Rr Tutik Sri. "Mengenal Systematic Review Theory Dan Studi Kasus." Jurnal Keperawatan Indonesia, vol. 13, no. 2, 2010, pp. 124-32, doi:10.7454/jki.v13i2.242.

Heong, Y. M., et al. "The Level Of Marzano Higher Order Thinking Skillsamong Technical Education Students." Internationall Journal Of Social Science And Humanity, vol. 1(2), 2011, pp. 121-125, doi:Https://Doi.Org/10.7763/ljssh.2011.V1.20.

Ilham S, Muhammad, Syarifuddin, Kune, Rukli. "Indonesian Journal of Primary 
Education Pengaruh Model Pembelajaran Radec Berbantuan Aplikasi Zoom." Indonesian Journal of Primary Education Pengaruh, vol. 4, no. 2, 2020, pp. 174-83.

Lestari, H., et al. "The Impact of Online Mentoring in Implementing Radec Learning to the Elementary School Teachers' Competence in Training Students' Critical Thinking Skills: A Case Study during Covid-19 Pandemic." Jurnal Pendidikan IPA Indonesia, vol. 10, no. 3, 2021, pp. 346-56, doi:10.15294/JPII.V10I3.28655.

Petrovska, Sonja, and Snezana Stavreva Veselinovska. "Contemporary Pedagogical Approaches for Developing Higher Level Thinking on Science Classes." Procedia - Social and Behavioral Sciences, vol. 92, no. Lumen, Elsevier B.V., 2013, pp. 702-10, doi:10.1016/j.sbspro.2013.08.742.

Pratama, Yoga Adi, Wahyu Sopandi, Yayuk Hidayah, et al. "Pengaruh Model Pembelajaran RADEC Terhadap Keterampilan Berpikir Tingkat Tinggi Siswa Sekolah Dasar." JINoP (Jurnal Inovasi Pembelajaran), vol. 6, no. 2, 2020, pp. 191-203, doi:10.22219/jinop.v6i2.12653.

---. "RADEC Learning Model (Read-Answer-Discuss-Explain And Create): The Importance of Building Critical Thinking Skills In Indonesian Context." International Journal for Educational and Vocational Studies, vol. 1, no. 2, 2019, pp. 109-15, doi:10.29103/ijevs.v1i2.1379.

Siswanto, Siswanto. "Systematic Review as a Research Method to Synthesize Research Results (Introduction)." Buletin Penelitian Sistem Kesehatan, vol. 13, no. 4, 2011, pp. 326-33.

Trilling, B., and C. Fadel. "21st Century Skills: Learning For Life In Our Times." San Francisco: Jossey- Bass A Wiley Imprint, 2009. 